\title{
AKIBAT HUKUM PELANGGARAN PRINSIP KEHATI-HATIAN DALAM PEMBERIAN KREDIT BANK
}

\author{
Henry Ananto Cahyono
}

Universitas Kristen, Indonesia

Email: henry.haplaw@gmail.com

\begin{tabular}{l}
\hline INFO ARTIKEL \\
\hline Diterima \\
25 Desember 2021 \\
Direvisi \\
05 Januari 2022 \\
Disetujui \\
15 Januari 2022 \\
\hline
\end{tabular}

Kata Kunci:

konsekuensi

hukum; prinsip

kehati-hatian; pinjaman bank

\section{ABSTRAK}

Dalam memberikan kredit bank selalu terdapat risiko, sehingga dalam menjalankan usahanya bank harus berpedoman pada dan menerapkan prinsip kehati-hatian dan prinsip pemberian kredit yang sehat. Asas kehati-hatian adalah asas bahwa bank dalam menjalankan fungsi dan kegiatan utamanya harus bertindak hatihati dalam rangka melindungi dana masyarakat yang dipercayakan kepadanya. Tidak menerapkan prinsip kehatihatian yang baik dalam pemberian pinjaman, hal ini dapat menimbulkan risiko dan permasalahan hukum. Metode penelitian mengenai akibat hukum dari pelanggaran prinsip kehati-hatian ini dibagi menjadi 2 (dua), yaitu (1) bagaimana prinsip kehati-hatian dalam pemberian kredit bank dan (2) apa akibat hukum dari pelanggaran prinsip kehati-hatian dalam pemberian kredit. kredit dalam Keputusan Nomor: 74/ Pid.Sus/TPK/2018/ PN. Bdg. Metode penelitian ini adalah yuridis normatif. Penerapan prinsip kehati-hatian dalam memberikan kredit kepada bank merupakan pemenuhan prinsip 5C, yaitu character; kapasitas; modal; kondisi; agunan. Kasus pemberian kredit Bank Mandiri Commercial Banking Center Bandung I kepada debitur PT. Tirta Amarta Bottling Company (TAB) mengabaikan prinsip kehati-hatian, dan yang paling krusial adalah kebenaran agunan (collateral) yang mengakibatkan masalah hukum bagi korupsi. Fungsi penjaminan dalam prinsip kehati-hatian menjadi pedoman bagi bank. jika dikemudian hari terdapat risiko gagal bayar, bank dapat menjual jaminan tersebut sebagai pengganti pinjaman yang telah diberikan. Penyelesaian pelanggaran prinsip kehati-hatian dalam pemberian kredit dalam putusan nomor 74/Pid.Sus/TPK/2018/PN.Bdg berupa konsep ganti rugi akibat perbuatan melawan hukum berdasarkan asumsi doktrin risiko dan Kelalaian komparatif doktrin. doktrin kelalaian komparatif). Kompensasi tersebut dapat diwujudkan melalui tuntutan ganti rugi yang sebenarnya, tuntutan ganti rugi yang berkaitan dengan tekanan jiwa, tuntutan ganti rugi di masa yang akan datang, dan tuntutan ganti rugi dengan adanya laporan tindak pidana pencucian uang sebagaimana diatur dalam Pasal 2 ayat (1) huruf r Undang-Undang Nomor 8 Tahun 2010 tentang Pencegahan dan

$\begin{array}{ll}\text { How to cite: } & \text { Cahyono, H. A. (2022) Akibat Hukum Pelanggaran Prinsip Kehati-Hatian dalam Pemberian Kredit } \\ & \text { Bank, Jurnal Syntax Admiration 3(1). https://doi.org/10.46799/jsa.v3i1.371 } \\ \text { E-ISSN: } & 2722-5356 \\ \text { Published by: } & \text { Ridwan Institute }\end{array}$


Pemberantasan Tindak Pidana Pencucian Uang.

\begin{abstract}
There is always a risk in providing bank credit, so that in carrying out its business, banks must be guided by and apply the prudential principles and the principles of healthy lending. The precautionary principle is the principle that banks in carrying out their main functions and activities must act prudently in order to protect public funds entrusted to them. Not applying the principle of good prudence in lending, this can lead to risks and legal problems. The research method regarding the legal consequences of violating the precautionary principle is divided into 2 (two), namely (1) how the principle of prudence is in providing bank credit and (2) what are the legal consequences of violating the precautionary principle in granting credit in Decision Number: 74/ Pid.Sus / TPK / 2018/ PN. Bdg. This research method is normative juridical. The implementation of the prudential principle in providing credit to banks is the fulfillment of the 5C principle, namely character; capacity; capital; conditions; collaterals. The case of granting credit to the Bank Mandiri Commercial Banking Center Bandung I to the debtor PT. Tirta Amarta Bottling Company (TAB) ignores the precautionary principle, and the most crucial thing is the truth of collateral (collateral) which results in legal problems for corruption. The guarantee function in the prudential principle serves as a guide for the bank. if in the future there is a risk of default, the bank can sell the guarantee as a substitute for the loan that has been given. Settlement of violations of the precautionary principle in granting credit in decision number 74/Pid.Sus/TPK/2018/PN.Bdg is in the form of the concept of compensation due to an unlawful act based on the assumption of risk doctrine and comparative Negligence doctrine. doctrine of comparative negligence). Such compensation can be realized through actual claims for compensation, claims for compensation related to mental stress, claims for future compensation, and claims for punitive damages with reports of money laundering crimes as regulated in Article 2 paragraph (1) letter $r$ Law Number 8 of 2010 concerning Prevention and Eradication of the Crime of Money Laundering.
\end{abstract}

Keywords: legal consequences; prudential principles; bank loans

\title{
Pendahuluan
}

Setiap pemberian kredit perbankan yang diberikan kepada masyarakat atau badan hokum selalu terdapat risiko, sehingga dalam menjalankan kegiatan usahanya bank harus selalu berpedoman dan menerapkan prinsip kehati-hatian serta asas-asas pemberian kredit yang sehat. Prinsip kehati-hatian harus diterapkan dalam bentuk melakukan hal tersebut secara konsisten berdasarkan niat baik terhadap semua 
persyaratan dan peraturan perundang-undangan yang terkait dengan pemberian kredit oleh bank yang bersangkutan. Tahapan-tahapan pemberian kredit yang baik diperlukan untuk melakukan persamaan antara praktek perkreditan yang dilakukan oleh perbankan dengan kebijakan perkreditan pada bank tersebut. Dengan adanya proses pemberian kredit yang baik tentunya dapat menghindari terjadinya praktik-praktik perkreditan yang tidak sehat. Kebijakan dan prosedur kredit yang baik harus diterapkan dan dilakukan secara penuh untuk tercapainya tujuan usaha.

Pada tahapan proses pemberian kredit harus selalu dilaksanakan dengan menerapkan prinsip kehati-hatian. Prinsip kehati-hatian tersebut terdapat dalam kebijakan pokok perkreditan. Kebijakan pokok pemberian kredit meliputi hal-hal utama pengaturan tata cara pemberian kredit yang sehat diantaranya adalah tata cara analisis dan penilaian kualitas kredit, profesionalisme dan integritas pejabat perkreditan (Suyatno, 2007).

Tata cara analisis adalah salah satu kebijakan pokok perkreditan yang sangat penting yaitu meliputi prosedur persetujuan kredit, prosedur dokumentasi dan administrasi kredit, dan proses pengawasan kredit. Adapun analisis yang digunakan oleh bank terhadap calon debitur dalam pemberian kredit yaitu dengan menggunakan prinsip yang telah dikenal dalam dunia perbankan sebagai Prinsip $5 \mathrm{C}$ (The Five C's Of Credit) . Prinsip 5 C terdiri Penilaian Watak (Character), Penilaian Kemampuan (Capacity), Penilaian Modal (Capital), Penilaian Agunan (Collateral), dan Penilaian terhadap prospek usaha debitur (Condition of Economy).

Prinsip $5 \mathrm{C}$ (The Five C's Of Credit) adalah sistem yang digunakan bank atau pemberi pinjaman lainnya untuk mengukur kelayakan kredit dari seorang calon debitur (peminjam). Analisis Prinsip 5 C merupakan salah satu bagian dari prinsip kehati-hatian pada bank untuk memberikan kredit kepada debitur karena itu pihak bank diwajibkan untuk menerapkan dan mengutamakan prinsip kehati-hatian tersebut dalam melakukan analisis kredit. Prinsip kehati-hatian (prudential banking) merupakan salah satu prinsip yang wajib dilaksanakan oleh setiap bank dalam pemberian kredit, baik yang beroperasi secara konvensional maupun syari'ah.

Prinsip kehati-hatian adalah suatu asas atau prinsip yang menyatakan bahwa bank di dalam menjalankan fungsi dan kegiatan utamanya wajib bersikap hati-hati (prudent) dalam rangka melindungi dana masyarakat yang dipercayakan kepadanya (Usman, 2001). Dalam menerapkan prinsip kehati-hatian, pihak bank sebagai kreditur, harus menjalankan perannya tersebut berlandaskan suatu kebijakaan untuk tetap memelihara keseimbangan antara keinginan untuk mendapatkan kreditur yang tepat dan memperoleh keuntungan dalam bentuk bunga.

Saat ini Pemerintah sudah memberikan perhatian pada penyempurnaan peraturanperaturan hukum di bidang perbankan. Penyempuraan peraturan hukum yang berhubungan dengan prudential regulation (peraturan yang menyangkut prinsip kehatihatian) sudah terlihat cukup memadai, tetapi nampaknya kelengkapan peraturan tersebut masih belum memadai untuk dijadikan tolok ukur bahwa perbankan nasional sudah bisa berjalan dengan baik dan tidak terdapat masalah di dalamnya. 
Salah satu faktor utama yang menjadi penyebab kurang baiknya sistem perbankan nasional adalah terdapat perbuatan dari para pengelola dan pemilik bank yang memanfaatkan dengan tidak benar dan mengabaikan prinsip kehati-hatian dalam menjalankan usaha di bidang perbankan. Hal ini juga ditambah dengan faktor lain yang juga penting yaitu pengawasan yang lemah.

Kasus kredit bermasalah masih kerap terjadi pada lembaga keuangan terutama pada sektor perbankan, hal ini terlihat pada pihak debitur yang mempunyai kesulitan dalam melakukan pelunasan kredit baik dengan sengaja atau tidak sengaja. Sebagai contoh kasus kredit bermasalah yang terjadi pada salah satu cabang PT Bank Mandiri (Persero) Tbk yaitu Cabang Bank Mandiri Commercial Banking Center Bandung I terhadap debiturnya PT. Tirta Amarta Bottling Company (PT. TAB). Kasus ini harus dijadikan pelajaran bagi Bank atau lembaga lain yang juga menyalurkan kredit harus menerapkan dan mengutamakan prinsip kehati-hatian.

\section{Metode Penelitian}

Berdasarkan latar belakang di atas, maka pokok permasalahan dalam penelitian ini adalah:

1) Bagaimanakah prinsip kehati-hatian dalam pemberian kredit bank?

2) Bagaimana akibat hukum pelanggaran prinsip kehati-hatian dalam pemberian kredit bank (Studi Kasus Putusan Nomor 74/Pid.Sus/TPK/2018/PN.Bdg)?

\section{Hasil dan Pembahasan}

\section{A. Prinsip Kehati-Hatian Dalam Pemberian Kredit Bank}

Hukum adalah untuk manusia, maka pelaksanaan hukum atau penegakan hukum harus memberi manfaat atau kegunaan bagi masyarakat (Rachman, 2021). Hal tersebut yang mendasari pula terciptanya prinsip kehati-hatian (prudent banking principle). Istilah prudent sangat terkait dengan pengawasan dan manajemen bank. Kata prudent itu sendiri secara harafiah dalam Bahasa Indonesia berarti kebijaksanaan, Namun dalam dunia perbankan istilah itu digunakan untuk asas kehati-hatian (Gandapradja, 2004).

Peraturan mengenai prinsip kehati-hatian (prudent banking principle) di Indonesia hingga saat ini sudah cukup memadai, bahkan sudah dilakukan revisi atau pergantian, baik setelah lahirnya UU No.7 tahun 1992 tentang Perbankan maupun ketika Pemerintah mengundangkan UU No. 10 tahun 1998 tentang Perubahan Atas Undang-Undang Nomor 7 Tahun 1992 tentang Perbankan. Regulasi tersebut sebagian besar diwujudkan dalam bentuk Surat Edaran dan SK Direksi Bank Indonesia.

Walaupun sudah ada aturan yang mengatur mengenai perbankan dan pemberian kredit, namun pada praktiknya pemberian kredit bank kepada nasabah masih seringkali tidak menerapkan prinsip kehati-hatian sesuai dengan peraturan perbankan. Mengenai pengaturan prinsip kehati-hatian pada perbankan diatur pada undangundang dan peraturan perbankan di Indonesia, diantaranya: 
1. Pasal 2 Undang-Undang Nomor 10 Tahun 1998 tentang Perubahan Atas UndangUndang Nomor 7 Tahun 1992 tentang Perbankan yang menyebutkan bahwa:

Perbankan Indonesia dalam melakukan usahanya berasaskan demokrasi ekonomi dengan menggunakan prinsip kehati-hatian.

Prinsip kehati-hatian (prudent banking principle) adalah suatu asas atau prinsip yang menyatakan bahwa bank dalam menjalankan fungsi dan kegiatan usahanya wajib bersikap hati-hati (prudent) dalam rangka melindungi dana masyarakat yang dipercayakan padanya.

Berdasarkan pasal tersebut dapat disimpulkan bahwa secara tegas pelaksanaan prinsip kehati-hatian merupakan hal yang utama dalam menjalankan bisnis perbankan namun pengertian dari prinsip kehati-hatian, di dalam UndangUndang Perbankan sama sekali tidak dijelaskan, dalam penjelasannya. UndangUndang Perbankan hanya menyebutkan istilah dan ruang lingkupnya saja yang secara explisit termuat di dalam Pasal 29 Ayat (2), (3) dan (4).

2. Pasal 29 ayat (2), (3) dan (4) Undang-Undang Nomor 10 tahun 1998 tentang Perubahan atas Undang-Undang Perbankan Nomor 7 tahun 1992 tentang Perbankan mengatur bahwa:

1) Bank wajib memelihara tingkat kesehatan bank sesuai dengan ketentuan kecukupan modal, kualitas aset, kualitas manajemen, likuiditas, rentabilitas, solvabilitas dan aspek lain yang berhubungan dengan usaha bank dan wajib melakukan kegiatan usaha sesuai dengan prinsip kehati-hatian.

2) Dalam memberikan kredit atau pembiayaan berdasarkan prinsip syariah dan melakukan kegiatan usaha lainnya, bank wajib menempuh cara-cara yang tidak merugikan bank dan kepentingan nasabah yang mempercayakan dananya kepada bank.

3) Untuk kepentingan nasabah, bank wajib menyediakan informasi mengenai kemungkinan timbulnya resiko kerugian sehubungan dengan transaksi nasabah yang dilakukan melalui bank.

3. Prinsip Kehati-hatian perbankan juga termaktub didalam Pasal 8, Pasal 10 dan Pasal 11 Undang-Undang Nomor 10 Tahun 1998 tentang Perubahan Atas UndangUndang Nomor 7 Tahun 1992 tentang Perbankan menyatakan:

Pasal 8

1) Dalam memberikan kredit atau pembiayaan berasarkan Prinsip Syariah, Bank Umum wajib mempunyai keyakinan berdasarkan analisis yang mendalam atau itikad dan kemampuan serta kesanggupan Nasabah Debitur untuk melunasi utangnya atau mengembalikan pembiayaan dimaksud sesuai dengan yang diperjanjikan.

2) Bank Umum wajib memiliki dan menerapkan pedoman perkreditan dan pembiayaan berdasarkan Prinsip Syariah, sesuai dengan ketentuan yang ditetapkan oleh Bank Indonesia. 
Berdasarkan pasal tersebut dapat disimpulkan bahwa dalam hal pemberian kredit bank wajib memiliki dan menerapkan pedoman perkreditan dan pembiayaan, sesuai dengan ketentuan yang ditetapkan oleh Bank Indonesia, yang sekarang menjadi wewenang Otoritas Jasa Keuangan dengan keluarnya UndangUndang Nomor 21 tahun 2011 tentang Otoritas Jasa Keuangan yang selanjutnya disebut UU OJK.

\section{Pasal 10}

"Bank Umum dilarang:

a. melakukan penyertaan modal, kecuali sebagaimana dimaksud dalam Pasal 7 huruf $b$ dan huruf c;

b. melakukan usaha perasuransian;

c. melakukan usaha lain di luar kegiatan usaha sebagaimana dimaksud dalam Pasal 6 dan Pasal 7.

\section{Pasal 11}

1) Bank Indonesia menetapkan ketentuan mengenai batas maksimum pemberian kredit atau pembiayaan berdasarkan Prinsip Syariah, pemberian jaminan, penempatan investasi surat berharga atau hal lain yang serupa, yang dapat dilakukan oleh bank kepada peminjam atau sekelompok peminjam yang terkait termasuk kepada perusahaanperusahaan dalam kelompok yang sama dengan bank yang bersangkutan.

2) Batas maksimum sebagaimana dimaksud dalam ayat (1) tidak boleh melebihi $30 \%$ (tiga puluh perseratus) dari modal bank yang sesuai dengan ketentuan yang ditetapkan oleh Bank Indonesia.

3) Bank Indonesia menetapkan ketentuan mengenai batas maksimum pemberikan kredit, atau pembiayaan berdasarkan Prinsip Syariah, pemberian jaminan, penempatan investasi surat berharga, atau hal lain yang serupa yang dapat dilakukan oleh bank kepada :

a. pemegang saham yang memiliki $10 \%$ (sepuluh perseratus) atau lebih dari modal disetor bank;

b. anggota Dewan Komisaris;

c. anggota Direksi;

d. keluarga dari pihak sebagaimana dimaksud dalam huruf a, huruf $b$, dan huruf c;

e. pejabat bank lainnya; dan

f. perusahaan-perusahaan yang di dalamnya terdapat kepentingan dari pihak-pihak sebagaimana dimaksud dalam huruf $a$, huruf $b$, huruf $c$, huruf d, dan huruf e.

g. Dalam memberikan kredit atau pembiayaan berdasarkan Prinsip Syariah, bank dilarang melampaui batas maksimum pemberian 
kredit atau pembiayaan berdasarkan Prinsip Syariah sebagaimana diatur dalam ayat (1), ayat (2), ayat (3) dan ayat (4).

4) Pasal 25 Undang-Undang Nomor 23 Tahun 1999 tentang Bank Indonesia menyatakan:

1) Dalam rangka melaksanakan tugas mengatur bank, Bank Indonesia berwenang menetapkan ketentuan-ketentuan perbankan yang memuat prinsip kehati-hatian,

2) Pelaksanaan kewenangan sebagaimana dimaksud pada ayat (1) ditetapkan dengan Peraturan Bank Indonesia.

Penjelasan dari pasal tersebut adalah:

Ketentuan-ketentuan perbankan yang memuat prinsip kehatihatian bertujuan untuk memberikan rambu-rambu bagi penyelenggaraan kegiatan usaha perbankan guna mewujudkan sistem perbankan yang sehat. Pengaturan bank berdasarkan prinsip kehati-hatian tersebut disesuaikan pula dengan standar yang berlaku secara internasional.

Hingga saat ini hal yang berkaitan dengan prinsip kehati-hatian perbankan di Indonesia sudah banyak diturunkan dan ditegaskan dalam peraturan-peraturan atau regulasi perbankan di Indonesia. Regulasi tersebut sebagian besar diwujudkan dalam bentuk Surat Edaran dan SK Direksi Bank Indonesia. Aturan-aturan tersebut misalnya:

a. SK BI 30/11/KEP/DIR/1997 tentang tata cara penilaian tingkat kesehatan bank

b. SK BI 30/12/KEP/DIR/1997 tentang tata cara penilaian tingkat kesehatan Bank Perkreditan Rakyat

c. SK BI 30/46/KEP/DIR/1997 tentang pembatasan pemberian kredit oleh bank umum untuk pembiayaan pengadaan dan atau pengolahan tanah

d. SK BI/31/16/UUPB/1998 tentang batas maksimum pemberian kredit bank umum

e. SK BI 31/177/KEP/DIR tentang batas maksimum pemberian kredit bank umum

f. SE BI 31/17/UUPB/1998 tentang posisi devisa neto bank umum

g. SE BI 31/18/UUPB/1998 tentang pemantauan likuiditas bank umum

h. SK BI 31/179/KEP/DIR tentang pemantauan likuiditas bank umum

i. SK BI 31/148/KEP/DIR/1998 tentang pembentukan penyisihan penghapusan aktiva produktif

j. SK BI 31/147/KEP/DIR/1998 tentang kualitas aktiva produktif

k. SK BI 331/178/KEP/DIR/1998 tentang posisi devisa neto bank umum

1. Peraturan BI $2 / 16 / \mathrm{PBI} / 2000$ tentang perubahan SK Direksi BI 31/177/KEP/DIR/1998 tentang batas maksimum pemberian kredit 
m. Peraturan BI 3/21/PBI/2001 tentang kewajiban penyediaan modal minimum bank]

n. Peraturan BI 3/22/PBI/2001 tentang transparansi kondisi keuangan bank

o. Peraturan $\mathrm{BI} 6 / 25 / \mathrm{PBI} / 2004$ tentang rencana bisnis bank umum

p. Peraturan BI 7/4/PBI/2005 tentang prinsip kehati-hatian dalam aktivitas sekuritisasi aset bagi bank umum

q. Peraturan Bank Indonesia No. 8/19/PBI/2006 tentang Kualitas Aktiva Produktif dan Pembentukan Penyisihan Penghapusan Aktiva Produktif Bank Perkreditan Rakyat

Prinsip kehati-hatian merupakan kewajiban yang harus diterapkan oleh bank dalam memberikan kredit. Kredit ataupun pembiayaan baik yang biasa atau yang berdasarkan prinsip syariah sangat berkaitan erat dengan risiko, sehingga dalam pelaksanaannya bank harus memperhatikan asas-asas perkreditan dan berdasarkan prinsip perbankan yang sehat. Bank harus menentukan kebijakan-kebijakan yang ditempuhnya dalam melaksanakan kegiatan usahanya sebagai lembaga yang memberikan kredit.

Pada pemberian kredit penerapan prinsip mengenal nasabah atau know your customer principle (KYC principle) juga merupakan suatu hal yang penting sejalan dengan prinsip kehati-hatian, hal tersebut didasari atas pertimbangan bahwa prinsip mengenal nasabah tidak saja penting dalam rangka pemberantasan kejahatan perbankan, tetapi juga dalam rangka penerapan prinsip kehati-hatian (prudential banking), hal ini untuk melindungi bank atau perusahaan jasa keuangan lain dari berbagai resiko dalam berhubungan dengan nasabah.

Pada proses pemberian kredit kepada nasabah ada beberapa analisis umum dan wajib harus dilakukan oleh bank ketika akan menganalisis kelayakan sebuah permohonan kredit, yaitu dengan Prinsip 5C, 7P dan dengan prinsip 3R.

1. Prinsip 5C, yaitu:

\section{a. Character (Penilaian Watak)}

Merupakan sifat atau watak seseorang. Sifat atau watak dari orangorang yang akan diberikan kredit benar-benar harus dipercaya. Untuk membaca watak atau sifat dari calon debitur dapat dilihat dari latar belakang si nasabah, baik yang bersifat pribadi seperti cara hidup atau gaya hidup yang dianutnya, keadaan keluarga, hobi dan dan jiwa social, kepatuhan akan janji serta kemauan untuk mengembalikan kredit.

b. Capacity (Penilaian Kemampuan)

Merupakan penilaian untuk melihat kemampuan nasabah dalam kemampuannya berbisnis yang dikaitkan dengan ketaatan pada peraturan pemerintah dan pendidikannya, sehingga pihak bank mampu melakukan penilaian terhadap kemampuan nasabah untuk melunasi kewajibankewajibannya dari usaha yang di dirikannya. 


\section{c. Capital (Penilaian Modal)}

Hal ini merupakan jumlah dana yang dimiliki oleh debitur untuk menjaga dan melangsungkan usahanya. Tujuan penilaian ini yaitu untuk mengetahui keadaan permodalah dan sumber dana serta penggunaannya.

d. Collateral (Penilaian Agunan)

Merupakan jaminan yang diberikan calon nasabah baik yang bersifat fisik maupun non fisik. Jaminan hendaknya melebihi jumlah kredit yang diberikan. Jaminan juga harus diteliti keabsahan dan kesempurnaannya, sehingga jika terjadi suatu masalah, maka jaminan yang dititipkan akan dapat dipergunakan secepat mungkin.

e. Condition of Economy (Penilaian terhadap prospek usaha debitur)

Kredit hendaknya dinilai dari kondisi ekonomi dan politiknya, serta prospek dari usaha yang dijalankan apakah memiliki prospek yang baik sehingga tidak menimbulkan kredit bermasalah.

2. Prinsip 7P, yaitu:

a. Personality

Personality merupakan hal yang digunakan untuk menilai nasabah dari segi kepribadian atau tingkah laku sehari-harinya maupun perilaku masa lalunya.

b. Party

Party di gunakan untuk mengklasifikasikan atau menggolongkan nasabah berdasarkan modal, loyalitas serta karakternya.

c. Purpose

Perpose digunakan untuk mengetahui tujuan nasabah untuk apa melakukan permohonan kredit, apakah memiliki aspek-aspek sosial yang positif serta luas atau tidak.

d. Prospect

Prospect di gunakan untuk menilai apakah prospek usahanya menguntungkan atau tidak di masa sekarang dan masa yang akan datang.

e. Payment

Payment merupakan ukuran bagaimana cara nasabah mengembalikan kredit yang telah di ambil atau darimana sajakah dana ynag akan di gunakan untuk melunasi kredit yang telah di terimanya.

f. Profitability

Profitability digunakan untuk menganalisis kemampuan nasabah dalam mencari laba. Hal ini di ukur dari satu period eke periode berikutnya.

\section{g. Protection}

Protection di gunakan untuk menjaga usaha dan jaminan yang telah dijaminkan agar tetap mendapatkan perlindungan, sehingga ketika terjadi hal yang tidak di inginkan bank tidak perlu melindungi kredit yangtelah di berikan. 
3. Prinsip 3R, yaitu:
a. Return

Return merupakan penilaian terhadap hasil yang akan di capai perusahaan, baik atau tidak ketika telah di biayai oleh kredit.

b. Repayment

Repayment merupakan penilaian mengenai waktu yang di butuhkan debitur untuk mengembalikan pinjamannya.

c. Risk Bearing Ability

Pihak bank harus mampu menganalisis sejauh mana nasabah yang mengajukan kredit mampu untuk menanggung risiko kegagalan semisal terjadi hal yang tidak di inginkan.

Berdasarkan uraian-uraian yang telah disebutkan diatas maka dapat diketahui bahwa landasan hukum yang mengatur prinsip kehati-hatian bank dalam pasal Undang-Undang Perbankan dan Peraturan Bank Indonesia, adalah bahwa pertama, Perbankan Indonesia dalam melakukan usahanya berasaskan demokrasi ekonomi dengan menggunakan prinsip kehatihatian (P. 2 Undang-Undang, 1992). Kedua, Dalam memberikan kredit atau pembiayaan berdasarkan Prinsip Syariah, Bank Umum wajib mempunyai keyakinan berdasarkan analisis yang mendalam atas iktikad dan kemampuan serta kesanggupan Nasabah Debitur untuk melunasi utangnya atau mengembalikan pembiayaan dimaksud sesuai dengan yang diperjanjikan (Undang-Undang Nomor 10 Tahun, 1998b).

Ketiga, Dalam memberikan kredit atau pembiayaan berdasarkan Prinsip Syariah dan melakukan kegiatan usaha lainnya, bank wajib menempuh cara-cara yang tidak merugikan bank dan kepentingan nasabah yang mempercayakan dananya kepada bank (Undang-Undang Nomor 10 Tahun, 1998a). Keempat, Penyediaan dana BPR pada Aktiva Produktif wajib dilaksanakan berdasarkan prinsip kehati-hatian (Pasal 2 Ayat 1 Peraturan Bank Indonesia No. 8/19/PBI/2006, 2006). Lebih lanjut, penjelasan pasal tersebut menyatakan bahwa, Penyediaan dana BPR pada Aktiva Produktif didasarkan pada penilaian atas kondisi usaha dan kemampuan membayar debitur, antara lain dengan memperhatikan faktor-faktor character, capital, capacity, condition of economy dan collateral. Dengan menelaah pasal-pasal di atas, jika terjadi pelanggaran pada pasal-pasal tersebut, maka dapat disimpulkan bahwa telah terjadi tindakan pelanggaran terhadap prinsip kehati-hatian bank.

\section{B. Akibat Hukum Pelanggaran Prinsip Kehati-Hatian Dalam Pemberian Kredit Bank}

Adanya pelanggaran hukum dalam pemberian fasilitas kredit kepada PT. Tirta Amarta Bottling Company (PT. TAB) menyebabkan kerugian bagi Bank Mandiri Commercial Banking Center Bandung I atau PT. Bank Mandiri (Persero), Tbk yang merupakan BUMN, maka penyelesaian dan perlindungan hukum yang diberikan negara kepada Bank Mandiri Commercial Banking Center Bandung I atas kebijakan pemberian kredit yang merugikan bank kepada direktur PT. Tirta Amarta Bottling 
Company (TAB) adalah dengan melakukan penuntutan hukum, baik secara pidana maupun secara perdata.

Sedangkan kepada pegawai Bank Mandiri Commercial Banking Center Bandung I penerapan ketentuan undang-undang yang paling tepat adalah berdasarkan Pasal 49 ayat (2) huruf b Undang-Undang Republik Indonesia Nomor 10 Tahun 1998 Tentang Perubahan Atas Undang-Undang Nomor 7 Tahun 1992 Tentang Perbankan yaitu:

1) Anggota Dewan Komisaris, Direksi, atau pegawai bank yang dengan sengaja:

a. meminta atau menerima, mengizinkan atau menyetujui untuk menerima suatu imbalan, komisi, uang tambahan, pelayanan, uang atau barang berharga, untuk keuntungan pribadinya atau untuk keuntungan keluarganya, dalam rangka mendapatkan atau berusaha mendapatkan bagi orang lain dalam memperoleh uang muka, bank garansi, atau fasilitas kredit dari bank, atau dalam rangka pembelian atau pendiskontoan oleh bank atas surat-surat wesel, surat promes, cek, dan kertas dagang atau bukti kewajiban lainnya, ataupun dalam rangka memberikan persetujuan bagi orang lain untuk melaksanakan penarikan dana yang melebihi batas kreditnya pada bank;

b. tidak melaksanakan langkah-langkah yang diperlukan untuk memastikan ketaatan bank terhadap ketentuan dalam Undang-undang ini dan ketentuan peraturan perundang-undangan lainnya yang berlaku bagi bank, diancam dengan pidana penjara sekurang-kurangnya 3 (tiga) tahun dan paling lama 8 (delapan) tahun serta denda sekurang-kurangnya Rp5.000.000.000,00 (lima miliar rupiah) dan paling banyak Rp100.000.000.000,00 (seratus miliar rupiah)."

Ketentuan tersebut lebih tepat dipergunakan dikarenakan pegawai Bank Mandiri Commercial Banking Center Bandung I tunduk pada ketentuan UndangUndang Nomor 10 Tahun 1998 tentang Tentang Perubahan Atas Undang-Undang Nomor 7 Tahun 1992 Tentang Perbankan yang dalam sistem di Indonesia berlaku asas lex specialis derogate legi generalis. (hukum yang bersifat khusus mengesampingkan hukum yang bersifat umum).

Berdasarkan hal tersebut, maka dalam kasus penyaluran kredit Bank Mandiri Commercial Banking Center Bandung I terhadap debiturnya PT. Tirta Amarta Bottling Company (PT. TAB) terdapat kelalaian yang dilakukan oleh para pegawai Bank Mandiri Commercial Banking Center Bandung I, yaitu proses pemberian kredit Nota Analisa Kredit (NAK) yang dibuat melanggar Standar Pedoman Operasional Perkreditan (Credit Operationals Wholesale) tahun 2008 dan melanggar Alur Proses Pemberian Kredit sebagaimana Standar Prosedur Kredit Commercial tahun 2012, serta melanggar Kebijakan Perkreditan Bank Mandiri tahun 2011, sehingga tentunya melanggar Pasal 49 ayat (2) huruf b Undang-Undang Republik Indonesia Nomor 10 Tahun 1998 Tentang Perubahan Atas Undang-Undang Nomor 7 Tahun 1992 Tentang Perbankan sehingga dapat dikenakan pula tanggung jawab hukum baik secara perdata maupun pidana sesuai dengan undang-undang perbankan. 
Dalam kasus kredit macet Bank Mandiri Commercial Banking Center Bandung I terhadap debiturnya PT. Tirta Amarta Bottling Company (PT. TAB), berdasarkan bahwa penegakan hukum harus memberi manfaat atau kegunaan bagi masyarakat maka upaya yang dapat dilakukan oleh bank dalam melindungi haknya atas kebijakan pemberian kredit yang merugikan bank adalah dengan mengajukan gugatan ke pengadilan melalui Pasal 1365 KUHPerdata, yaitu perbuatan melawan hukum. Pasal 1365 KUHPerdata mengandung prinsip "liability based on fault" dengan beban pembuktian pada pihak yang dirugikan. Hal tersebut sejalan dengan Pasal 1865 KUHPerdata yang menentukan bahwa setiap orang yang mendalilkan bahwa ia mempunyai sesuatu hak, atau guna meneguhkan haknya sendiri maupun membantah suatu hak orang lain, menunjuk pada suatu peristiwa diwajibkan membuktikan adanya hak atau peristiwa tersebut.

Dalam upaya menuntut ganti rugi yang dideritanya, maka Bank Mandiri Commercial Banking Center Bandung I selaku Penggugat secara hukum lebih dapat membuktikan adanya perbuatan melawan hukum yang dilakukan oleh Rony Tedy selaku direktur PT. Tirta Amarta Bottling Company (PT. TAB), sehingga secara hukum, Bank Mandiri Commercial Banking Center Bandung I selaku Penggugat dapat menuntut ganti rugi yang dideritanya kepada Rony Tedy selaku direktur PT. Tirta Amarta Bottling Company (PT.TAB).

Selain daripada itu, hal lain yang perlu diperhatikan adalah jenis perbuatan melawan hukum yang dapat diterapkan kepada Rony Tedy selaku direktur PT. Tirta Amarta Bottling Company (PT. TAB). Hal tersebut dikarenakan dalam perbuatan melawan hukum, terdapat beberapa doktrin yang dapat diterapkan, sehingga dalam pengajuan gugatan hukum dapat diterima oleh majelis hakim.

Berdasarkan analisis penelitian kasus, maka doktrin yang tepat untuk diterapkan adalah doktrin asumsi risiko (assumption of risk) dan doktrin comparative negligence (doktrin kelalaian komparatif). Bentuk prototip dari doktrin asumsi risiko (assumption of risk) mengajarkan bahwa jika seorang korban dari perbuatan melawan hukum, tetapi korban tersebut telah setuju (secara tegas atau tersirat) secara sukarela untuk menanggung sendiri risiko yang mungkin timbul sebagai akibat dari perbuatan melawan hukum, maka pihak korban tersebut tidak berhak sama sekali atas ganti rugi atas kerugian karena perbuatan melawan hukum tersebut. Akan tetapi dalam perkembangan dari doktrin asumsi risiko tersebut, terjadi perkembangan dimana asumsi risiko tidak lagi melarang secara total perolehan ganti rugi oleh korban, tetapi perolehan ganti rugi menjadi berkurang berdasarkan prinsip comparative negligence (kelalaian komparatif). Dalam hal ini pihak korban dianggap ikut berkontribusi terhadap terjadinya kerugian tersebut.

Hal tersebut terjadi dalam kasus antara Bank Mandiri Commercial Banking Center Bandung I dengan Rony Tedy selaku direktur PT. Tirta Amarta Bottling Company (TAB). Fakta persidangan menyebutkan pihak Bank Mandiri Commercial Banking Center Bandung I menyetujui permohonan Rony Tedy selaku direktur PT. Tirta Amarta Bottling Company (TAB) terkait fasilitas kredit modal kerja (KMK) 
kepada sejak tanggal 19 Desember 2008. Di posisi inilah doktrin asumsi risiko masuk, yaitu Bank Mandiri Commercial Banking Center Bandung I selaku korban tersebut telah setuju (secara tegas atau tersirat).

Doktrin asumsi risiko dapat diperkuat dengan kriteria situasi dan kondisi mental dari korban dalam perbuatan melawan hukum. Dalam fakta persidangan juga terungkap bahwa Bank Mandiri Commercial Banking Center Bandung I setuju memberikan fasilitas kredit/perbankan kepada PT. Tirta Amarta Bottling Company (TAB) dan Bank Mandiri Commercial Banking Center Bandung I menyetujui perpanjangan dan tambahan fasilitas kredit kepada PT Bank Mandiri Tbk Commercial Banking Center Bandung. Dengan perpanjangan fasilitas Kredit Modal Kerja (KMK) sebesar Rp 880,6 miliar, palfon LC sebesar Rp 40 miliar dan fasilitas Kredit Investasi sebesar Rp 250 miliar selama 72 bulan.

Pada kenyataannya dokumen yang diberikan PT. Tirta Amarta Bottling Company (TAB) merupakan dokumen yang telah dipalsukan isinya, yaitu PT. Tirta Amarta Bottling Company (TAB) diketahui memperbesar aset terlebih pada piutang agar memperoleh kepercayaan dari PT Bank Mandiri dan juga seolah-olah kondisi keuangan PT. Tirta Amarta Bottling Company (TAB) menunjukan perkembangan. Sehingga perusahaan PT. Tirta Amarta Bottling Company (TAB) akhirnya bisa memperoleh perpanjangan dan tambahan fasilitas kredit pada 2015 sebesar Rp1,17 trilliun. Pada bagian tersebut, maka doktrin comparative negligence (doktrin kelalaian komparatif) berjalan, yaitu lalainya pegawai bank Bank Mandiri Commercial Banking Center Bandung I untuk memastikan bahwa mekanisme SOP (Standard Operating Procedure), Prudential Principle, serta Prinsip 5C untuk memberikan kredit kepada nasabah debitur sudah berjalan dengan baik atau tidak.

Doktrin asumsi risiko dan doktrin kelalaian komparatif dapat diperkuat dengan kriteria situasi dan kondisi mental dari korban, dan kriteria jenis perbuatan melawan hukum, dalam hal ini adalah jenis kelalaian. Dalam fakta persidangan juga terungkap bahwa Bank Mandiri Commercial Banking Center Bandung I setuju memberikan kredit modal kerja (KMK) dikarenakan PT. Tirta Amarta Bottling Company (TAB) merupakan nasabah lama dari Bank Mandiri CBC Bandung I Ciri khas dari kriteria situasi dan kondisi mental dari korban dalam perbuatan melawan hukum adalah dapat dianalisa bahwa korban kejahatan juga berperan penting dalam terjadinya kejahatan tersebut, sehingga dengan doktrin asumsi risiko dan doktrin kelalaian komparatif, maka terlihat adanya kelalaian pegawai Bank Mandiri Commercial Banking Center Bandung I yang turut terjadi kasus tersebut.

Salah satu unsur pokok kelalaian adalah adanya suatu kewajiban kehati-hatian. Kewajiban kehati-hatian dalam kasus Bank Mandiri Commercial Banking Center Bandung I adalah memastikan bahwa segala SOP (Standard Operating Procedure), Prudential Principle, serta Prinsip 5C untuk memberikan kredit kepada nasabah debitur sudah dilakukan dengan benar. Namun dalam kenyataannya adalah pegawai Bank Mandiri Commercial Banking Center Bandung I telah lalai dalam pengawasan tersebut, sehingga berakibat kerugian Bank Mandiri CBC Bandung I Akibat 
kelalaian tersebut, sehingga pegawai Bank Mandiri Commercial Banking Center Bandung I juga turut serta untuk bertanggung jawab.

Penulis berpendapat, dengan menggunakan doktrin assumption of risk (doktrin asumsi risiko) dan doktrin comparative negligence (doktrin kelalaian komparatif) dan dikuatkan dengan kriteria situasi dan kondisi mental dari korban, dan kriteria jenis perbuatan melawan hukum, dalam hal ini adalah jenis kelalaian, maka kerugian yang dialami oleh Bank Mandiri Commercial Banking Center Bandung I adalah kerugian materiil, yaitu seluruh fasilitas kredit yang dicairkan oleh pihak Bank Mandiri Commercial Banking Center Bandung I, sebesar Rp. 1,83 triliun.

Berdasarkan kasus tersebut, maka penyelesaian pelanggaran prinsip kehatihatian dalam pemberian kredit pada putusan nomor 74/Pid.Sus/TPK/2018/PN.Bdg adalah berupa konsep ganti rugi akibat adanya perbuatan melawan hukum berdasarkan doktrin assumption of risk (doktrin asumsi risiko) dan doktrin comparative negligence (doktrin kelalaian komparatif) dikuatkan dengan kriteria situasi dan kondisi mental dari korban, dan kriteria jenis perbuatan melawan hukum, dalam hal ini adalah jenis kelalaian, yaitu:

1. Tuntutan Ganti Rugi Yang Aktual

Ganti rugi yang aktual merupakan ganti rugi terhadap kerugian yang benarbenar telah dialami secara nyata. Ganti rugi yang aktual adalah ganti rugi yang paling umum dan gampang diterima oleh hukum, baik dalam hal perbuatan melawan hukum maupun dalam hal wanprestasi kontrak.

Dalam hal ganti rugi yang sepatutnya diminta oleh badan hukum akibat adanya perbuatan melawan hukum, maka tuntutan ganti rugi yang aktual adalah kerugian finansial, seperti biaya pengurusan perkara selama di persidangan.

2. Tuntutan Ganti Rugi Yang Berhubungan Dengan Tekanan Mental

Dalam hal ganti rugi yang sepatutnya diminta oleh badan hukum akibat adanya perbuatan melawan hukum, maka tuntutan ganti rugi yang berhubungan dengan tekanan mental adalah pemulihan nama baik perusahaan dengan cara seperti biaya untuk membuat iklan klarifikasi pada media nasional baik elektronik maupun cetak selama 7 (tujuh) hari berturut-turut yang seluruh biayanya dibebankan kepada pelaku. Namun demikian, oleh karena terdapatnya persetujuan dan juga kelalaian yang dilakukan oleh pegawai Bank Mandiri Commercial Banking Center Bandung I, maka kerugian immateriil tidak dapat diterima.

3. Tuntutan Ganti Rugi Yang Akan Datang

Ganti rugi untuk kerugian yang akan datang (future lost) juga mungkin diterapkan. Ganti rugi terhadap kerugian yang akan datang mestilah terhadap kerugian yang akan datang yang dapat dibayangkan yang wajar dan secara nyata akan terjadi. Jadi, bukan kerugian yang cuma dikhayalkan atau dikarang-karang. Dalam hal ganti rugi yang sepatutnya diminta oleh badan hukum akibat adanya perbuatan melawan hukum, maka tuntutan ganti rugi yang akan datang.

4. Tuntutan Ganti Rugi Penghukuman 
Dalam hal ganti rugi yang sepatutnya diminta oleh badan hukum akibat adanya perbuatan melawan hukum, maka tuntutan ganti rugi penghukuman dapat seperti Bank Mandiri Commercial Banking Center Bandung I menggugat PT. Tirta Amarta Bottling Company (TAB) sebesar Rp. 2 triliun, oleh karena perbuatan yang dilakukan oleh PT. Tirta Amarta Bottling Company (TAB) berakibat pencemaran nama baik Bank Mandiri CBC Bandung I.

Berdasarkan hal tersebut, penyelesaian secara perdata lebih bermanfaat dibandingkan dengan penyelesaian secara pidana, dikarenakan pihak bank mengalami kerugian secara perdata, sehingga dalam bisnis, pergantian kerugian secara materi lebih dibutuhkan dibandingkan dengan memenjarakan orang. Sekalipun menggunakan penyelesaian secara pidana, maka pihak Bank Mandiri Commercial Banking Center Bandung I dapat melaporkan Rony Tedy selaku direktur PT. Tirta Amarta Bottling Company (TAB) dengan laporan tindak pidana pencucian uang sebagaimana diatur dalam Pasal 2 ayat (1) huruf $r$ Undang-Undang Nomor 8 Tahun 2010 tentang Pencegahan dan Pemberantasan Tindak Pidana Pencucian Uang.

Korban tindak pidana pencucian uang dalam putusan ini mempunyai hak atas kompensasi yang diberikan negara. Konpensasi juga bisa dilakukan dengan cara restitusi. Restitusi muncul ketika gerakan terhadap hak-hak korban memunculkan sentimen bahwa sistem peradilan pidana terlalu menitikberatkan kepada pelaku kejahatan dan seringkali gagal untuk memenuhi kepentingan dan kebutuhan korban kejahatan. Melalui restitusi pelaku kejahatan dimintai pertanggungjawaban atas kerugian yang dialami korban.

Restitusi mempunyai tujuan, yakni mengganti kerugian yang dialami korban maupun untuk memidana pelaku; Menelusuri kerugian yang disebabkan oleh (pelaku) kejahatan berfungsi sebagai instrumen pencegahan karena memberikan peringatan kepada pelaku potensial bahwa mereka juga akan dimintai pertanggungjawaban atas setiap kerugian yang ditimbulkan; Memaksa pelaku kejahatan untuk mengakui kerugian yang disebabkan perbuatannya dengan memerintahkannya membayar sejumlah uang kepada korban (Susanto, 2020).

Pasal 67 Undang-Undang Nomor 8 Tahun 2010 tentang Pencegahan dan Pemberantasan Tindak Pidana Pencucian Uang memberikan kewenangan kepada penyidik untuk mengajukan permohonan kepada pengadilan negeri untuk memutuskan aset yang diduga merupakan hasil tindak pidana untuk dijadikan aset negara atau dikembalikan kepada yang berhak. Pasal ini menyebutkan:

a. Dalam hal tidak ada orang dan/atau pihak ketiga yang mengajukan keberatan dalam waktu 20 (dua puluh) hari sejak tanggal penghentian sementara transaksi, PPATK menyerahkan penanganan harta kekayaan yang diketahui atau patut diduga merupakan hasil tindak pidana tersebut kepada penyidik untuk dilakukan penyidikan.

b. Dalam hal yang diduga sebagai pelaku tindak pidana tidak ditemukan dalam waktu 30 (tiga puluh) hari, penyidik dapat mengajukan permohonan kepada 
pengadilan negeri untuk memutuskan harta kekayaan tersebut sebagai aset negara atau dikembalikan kepada yang berhak.

c. Pengadilan sebagaimana dimaksud pada ayat (2) harus memutus dalam waktu paling lama 7 (tujuh) hari.

Berkaitan dengan pengembalian kepada pihak yang berhak dalam hal ini, merupakan salah satu wujud dari asset recovery korban selain penempatan aset tindak pidana pencucian uang tersebut sebagai aset negara. Dalam kasus penelitian ini melibatkan badan usaha swasta, yaitu PT. Tirta Amarta Bottling Company (TAB) dalam kasus tindak pidana pencucian uang, sehingga aset tersebut tidak dapat diklaim negara.

\section{Kesimpulan}

Kesimpulan dalam penelitian ini adalah: 1) Prinsip kehati-hatian adalah suatu asas yang mengatakan bahwa bank dalam menjalankan fungsi dan kegiatan usahanya wajib menerapkan prinsip kehati-hatian dalam rangka melindungi dana masyarakat yang dipercayakan padanya. Prinsip ini disebutkan dalam Undang-Undang Nomor 10 Tahun 1998 tentang Perubahan Atas Undang-Undang Nomor 7 Tahun 1992 tentang Perbankan. Penerapan pelaksanaan prinsip kehati-hatian merupakan kewajiban atau keharusan bagi bank untuk memperhatikan, mengindahkan dan melaksanakannya. Pelaksanaan prinsip kehati-hatian dalam pemberian kredit pada perbankan adalah wajib terpenuhinya prinsip 5C, yaitu character; capacity; capital; condition; collateral. Bank harus tetap konsisten dalam menjalankan prinsip kehati- hatian (prudential banking principle), tidak hanya pada tahap awal proses pemberian pembiayaan saja akan tetapi juga pada saat setelah pembiayaan dicairkan dengan melakukan pembinaan dan pengawasan terhadap nasabahnya. Hal ini sangat penting sebagai langkah preventif untuk menghindari terjadinya pembiayaan bermasalah yang dapat mempengaruhi tingkat kesehatan bank. Pelanggaran atas prinsip kehati-hatian (prudential banking principle) juga berakibat menjadi permasalahan hukum. 2) Akibat hukum pelanggaran prinsip kehati-hatian dalam pemberian kredit bank masih terjadi perbedaan penerapan hukum dan sanksi dalam penyelesaianya. Dalam perkembangannya pelanggaran prinsip kehati-hatian dalam pemberian kredit bank dikategorikan sebagai tindak pidana korupsi apabila terdapat kerugian negara pada bank milik pemerintah (BUMN). Hal lain akibat hukum pelanggaran prinsip kehati-hatian dalam pemberian kredit bank yang mengakibatkan kredit macet dapat dikategorikan Tindakan korupsi karena adanya perluasan didalam Pasal 14 Undang-Undang Nomor 31 Tahun 1999 juncto UndangUndang Nomor 20 Tahun 2001 tentang Perubahan Undang-Undang Nomor 31 Tahun 1999 tentang Pemberantasan Tindak Pidana Korupsi (UU Tipikor). Pasal tersebut dapat diartikan undang-undang tentang Pemberantasan Tindak Pidana Korupsi dapat juga digunakan untuk mengadili tindak pidana lain seperti; tindak pidana perbankan, dan tindak pidana lainnya, selama tindak pidana dalam undang-undang terkait mengkualifikasikan sebagai tindak pidana korupsi, maka dalam hal penegakan hukumnya muncul dualisme pemberlakuan undang-undang, mana yang harus 
diterapkan, mana yang termasuk tindak pidana korupsi mana yang termasuk sebagai tindak pidana lain. Dalam kasus PT. TAB tidak dapat diterapkan Undang-Undang Nomor 31 tahun 1999 jo Undang-Undang Nomor 20 Tahun 2011 Tentang Pemberantasan Tindak Korupsi, namun seharusnya diterapkan melalui penerapan Undang-Undang Perbankan dan Perdata mengingat salah satu pihaknya adalah bank dan permasalahan yang timbul merupakan permasalahan di bidang perbankan akibat mengabaikan prinsip kehati-hatian (prudential banking principle) pemberian kredit Bank Mandiri Commercial Banking Center Bandung I terhadap debiturnya PT. Tirta Amarta Bottling Company (PT. TAB) yang didasarkan atas adanya perjanjian. 
Akibat Hukum Pelanggaran Prinsip Kehati-Hatian dalam Pemberian Kredit Bank

\section{BIBLIOGRAFI}

Gandapradja, P. (2004). Dasar dan Prinsip Pengawasan Bank. Jakarta: PT. Gramedia Pustaka Utama. Google Scholar

Handoko, D. (2018). Kitab undang-undang hukum pidana. Hawa dan AHWA. Google Scholar

Indonesia, P. R. (2001). Undang-Undang Republik Indonesia Nomor 20 Tahun 2001 Tentang Perubahan Atas Undang-Undang Nomor 31 Tahun 1999 Tentang Pemberantasan Tindak Pidana Korupsi. Google Scholar

Indonesia, R. (2002). Undang-Undang Dasar Negara Republik Indonesia Tahun 1945. Sekretariat Jenderal MPR RI. Google Scholar

Indonesia, R. (2010). Undang-Undang Nomor 8 Tahun 2010 Tentang Pencegahan dan Pemberantasan Tindak Pidana Pencucian Uang. Lembaran Negara RI Tahun. Google Scholar

Meliala, D. S. (2018). Hukum Waris Menurut Kitab Undang-Undang Hukum Perdata. Nuansa Aulia. Google Scholar

Pasal 2 Ayat 1 Peraturan Bank Indonesia No. 8/19/PBI/2006. (2006). Pasal 2 Ayat 1 Peraturan Bank Indonesia No. 8/19/PBI/2006 tentang Kualitas Aktiva Produktif dan Pembentukan Penyisihan Penghapusan Aktiva Produktif Bank Perkreditan Rakyat. Google Scholar

Rachman, H. (2021). Pengakuan Bersalah Terdakwa Dalam Sistem Peradilan Pidana. Bekasi: CV. Intelektual Writer. Google Scholar

Susanto. (2020). Penafsiran Asas Manfaat Tentang Asset Recovery Korban Tindak Pidana Pencucian Uang: Kajian Putusan Nomor 195 K/PDT/2018. Jurnal Yudisial, 13(1), 90. Google Scholar

Suyatno, T. (2007). dkk, Dasar-Dasar Perkreditan (Edisi Keempat). PT. Gramedia Pustaka Utama, Jakarta. Google Scholar

Undang-Undang Nomor 10 Tahun. (1998a). Pasal 29 ayat (3) Undang-Undang Nomor 10 Tahun 1998 tentang Perubahan Atas UndangUndang Nomor 7 Tahun 1992 tentang Perbankan. Google Scholar

Undang-Undang Nomor 10 Tahun. (1998b). Pasal 8 Ayat (1) Undang-Undang Nomor 10 Tahun 1998 tentang Perubahan Atas UndangUndang Nomor 7 Tahun 1992 tentang Perbankan. Google Scholar

Undang-Undang, P. 2. (1992). Pasal 2 Undang-Undang Nomor 7 Tahun 1992 tentang Perbankan. Google Scholar 
Henry Ananto Cahyono

Undang-Undang, R. I. (1998). Nomor 10 tahun 1998 Tentang Perubahan Atas UndangUndang Nomor 7 tahun 1992 Tentang Perbankan. Lembaran Negara Republik Indonesia. Google Scholar

Usman, R. (2001). Aspek-aspek hukum perbankan di Indonesia. Gramedia Pustaka Utama. Google Scholar

\section{Copyright holder:}

Henry Ananto Cahyono (2022)

First publication right:

Jurnal Syntax Admiration

This article is licensed under:

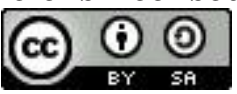

